\title{
The Levels of Biotin and Biotinidase in Bovine Milk
}

\author{
Masahiko Hirano, Kazuhiro Honma, Takaki Daimatsu, \\ Kou Hayakawa*, Jun Oizumi* Koji Zaima \\ and Yusuke KANKE \\ Faculty of Agriculture, Tokyo University of \\ Agriculture, Setagaya-ku, Tokyo 156 \\ *National Children's Medical Research Center, \\ Setagaya-ku, Tokyo 154
}

(Received Apri1 24, 1991)

\begin{abstract}
The concentrations of total biotin and free-form biotin in bovine milk have been determined by a new disc plate method. Increases in the contents of both total and free-form biotins were found in mature milk compared with colostrum. The ratio of free-form biotin to total biotin was approximately 0.81 in colostrum, and it did not change throughout lactation period studied. The activity of biotinidase in bovine milk increased during lactation as the free-form and total biotin contents gradually increased. These observations might suggest that biotinidase plays a role in keeping the ratio of free-form biotin to total biotin constant in bovine milk.

Anim. Sci. Technol. (Jpn.) 62 (11) : 1048-1054, 1991
\end{abstract}

Key words: free-form biotin, total biotin, biotinidase, bovine milk

Biotin has important roles as a co-factor in many enzyme systems involved in carboxylation reactions that influence carbohydrate metabolism, fatty acid and protein synthesis and nucleic acid metabolism. However, higher mammals including humans cannot synthesize biotin, therefore, they must obtain the vitamin by intestinal absorption ${ }^{20 !}$.

Most of biotin in foods is protein-bound form ${ }^{11,221}$, but only free form biotin can be absorbed from the jejunum tract ${ }^{3.19}$. The enzyme, biotinidase, specifically releases the biotin from the protein-bound form ${ }^{13,14,21}$. Thus, it is likely that biotinidase plays an important role in absorption of biotin.

It has been demonstrated that placental transport of biotin occurs in fetal period, and the concentration of biotin in cord blood is higher than that in maternal blood ${ }^{1,21}$. There- fore, biotin is also imporatant during fetal period and infancy, and biotin deficiency can be found in the sucking infants and young animals ${ }^{5)}$.

Although there were a few reports on the biotin contents in bovine milk $^{4,9,16)}$, the ratio of the two biotin forms in bovine milk has not yet been studied. In this study, the concentrations of total and free-form biotin in bovine milk were determined by our new disc plate method $^{\text {7) }}$ using Lactobacillus plantarum ATCC 8014. The new method distinguishes free-form from bound-form biotin. Furthermore, we determined the activity of bovine milk biotinidase, and the significant role of the enzyme was discussed.

\section{Materials and Methods}

The samples were obtained by hand in the 
morning from four healthy lactating Holsteins at the University Farm every other day for 14 days after delivery and once a week for following 3 months. The samples obtained from animals with symptoms of mastitis or administered antibiotics were excluded.

The specimens were frozen at $-80^{\circ} \mathrm{C}$ until analysis to determine the biotin concentrations and the biotinidase activities.

The milk samples were hydrolysed by autoclaving at $120^{\circ} \mathrm{C}$ for 60 minutes with $6 \mathrm{~N}$ $\mathrm{H}_{2} \mathrm{SO}_{4}$, and neutralized with $6 \mathrm{~N} \mathrm{NaOH}$; for the free-form biotin assay this treatment was omitted. These samples were used for the determination of total and free-form biotin by the method of FuKui et al. ${ }^{7}$.

Briefly, the agarose medium plates containing the organism were prepared, and the holes with $3 \mathrm{~mm}$ in diameter were made on the plate. Then the samples were applied into the holes, and incubated overnight at $37^{\circ} \mathrm{C}$. After incubation, the diameters of growth rings were measured.

The recoveries of the total and free-form biotins were $103.6 \pm 16.1 \%$ and $92.6 \pm 8.8 \%$, respectively.

The biotinidase activity in the milk was determined by HPLC-fluorometric method ${ }^{12)}$ using $\mathrm{N}-[(+)$-biotinyl]-p-aminobenzoate (biotPABA) as substrate. The milk was mixed with substrate solution (10 mg of biot-PABA in $100 \mathrm{~m} l$ of $0.1 \mathrm{M}$ sodium phosphate buffer, $\mathrm{pH} 6.4$ ). After incubation at $37^{\circ} \mathrm{C}$ for 3 hours, the mixture was applied into the HPLC system to separate PABA liberated. The HPIC was carried out using a reversed-phase HPLC column $(50 \times 4.0 \mathrm{~mm}$ I.D., manually packed with Develosil ODS, Nomura Chemical) equipped with a Waters 600 pump and a Hitachi F-3000 fluorimeter and using $0.1 \%$ aqueous trifluoroacetic acid as eluent. The amount of enzymatic reaction product was calculated by measuring the height of the PABA peak.

The specific enzyme activity was expressed as molality of PABA liberated by the enzyme per minute per mg of protein. Protein concentration was determined by the method of Lowry et al. ${ }^{17)}$, using bovine serum albumin as a standard protein. Statistical comparisons were made by using the Student's $\mathrm{t}$ test; $\mathrm{p}$ values greater than 0.05 were considered not significantly different.

\section{Results}

Table 1 summarizes the changes in various parameters in the bovine milk samples at 3 different lactating stages. There were the samples of 11 colostrum (up to 5 days postpartum), 19 transitional milk (6 to 14 days postpartum), and 19 mature milk (15 to 98 days postpartum).

Compared with colostrum, the free-form biotin contents in transitional and mature milk significantly increased 2.3 -fold and 4.6 -fold, respectively. Likewise, the total biotin contents increased 2.3-fold and 4.6-fold in transi-

Table 1. The concentrations of total and free-form biotin and biotinidase activities in bovine milk

\begin{tabular}{lccccc}
\hline & & $\begin{array}{c}\text { Free-form biotin } \\
(\mathrm{ng} / \mathrm{m} l)\end{array}$ & $\begin{array}{c}\text { Total biotin } \\
(\mathrm{ng} / \mathrm{m} l)\end{array}$ & $\begin{array}{c}\text { Free/Total ratio } \\
(\%)\end{array}$ & $\begin{array}{c}\text { Biotinidase activity } \\
(\mathrm{pmol} / \mathrm{min} / \mathrm{mg})\end{array}$ \\
\hline Colostrum & $(\mathrm{N}=11)$ & $4.1 \pm 2.5$ & $5.1 \pm 3.3$ & $81.6 \pm 8.5$ & $0.7 \pm 0.4$ \\
Transitional milk & $(\mathrm{N}=19)$ & $9.3 \pm 4.9^{\mathrm{a}}$ & $11.7 \pm 6.3$ & $80.9 \pm 10.3$ & $1.1 \pm 0.5^{\mathrm{D}}$ \\
Mature milk & $(\mathrm{N}=19)$ & $19.0 \pm 9.3^{\mathrm{a}, \mathrm{c}}$ & $23.6 \pm 11.4^{\mathrm{a}, \mathrm{c}}$ & $81.4 \pm 7.9$ & $1.9 \pm 0.5^{\mathrm{a}, \mathrm{c}}$ \\
\hline
\end{tabular}

Values are expressed as the mean of data \pm standard deviation.

a) Significant different $(p<0.01)$ from the value in colostrum.

b) Significant different $(p<0.05)$ from the value in colostrum.

c) Significant different $(p<0.05)$ from the value in transitional milk. 
Hirano, Honma, Daimatsu, Hayakawa, Oizumi, Zaima and Kanke
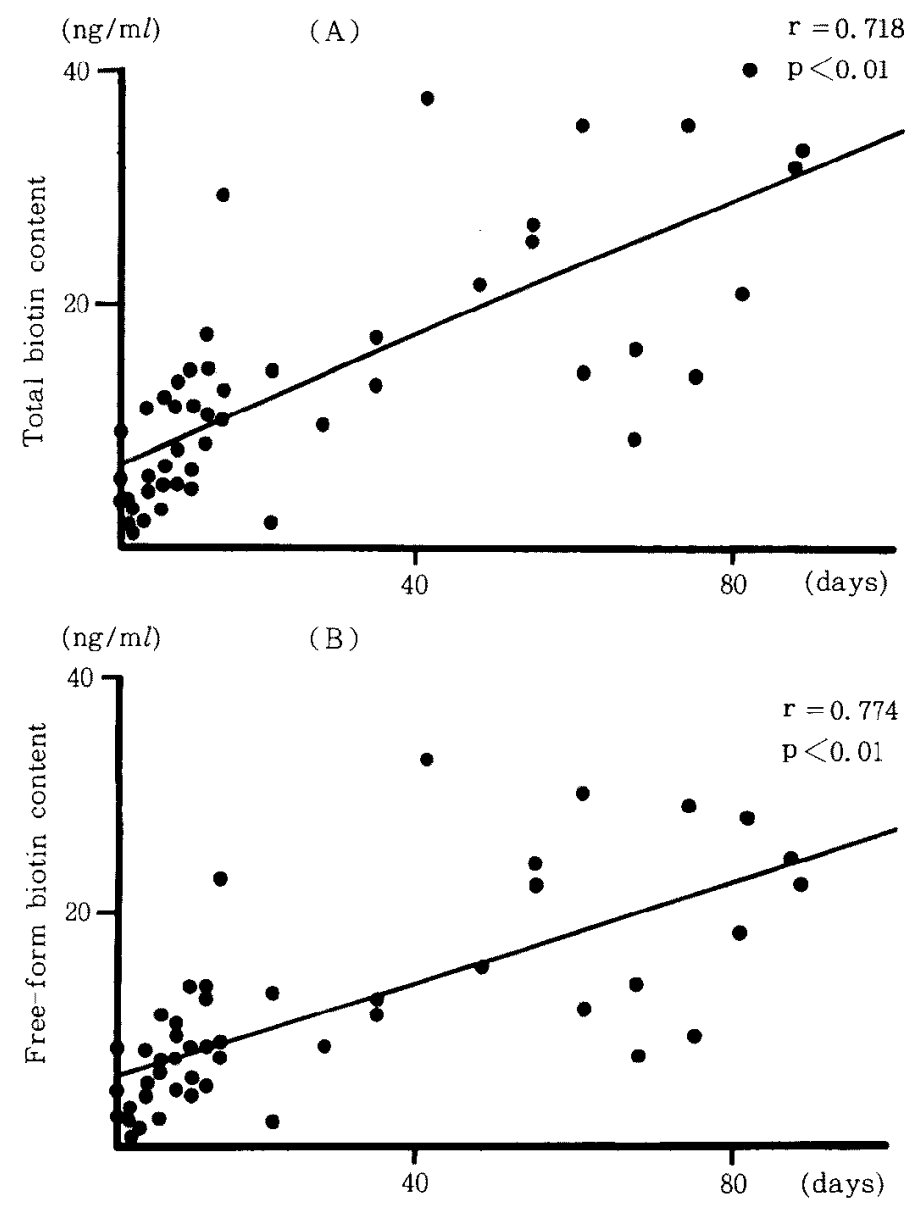

Days of lactation

Fig. 1. The relationship between the days of lactation and total (A) and free-form (B) biotin content in bovine milk.

tional and mature milk, respectively, compared with colostrum.

The ratio of free-form biotin to total biotin, approximately 0.81 , did not change throughout lactation. The biotinidase activity was $0.7 \pm$ $0.4 \mathrm{pmol} / \mathrm{min} / \mathrm{mg}$ in colostrum, and increased 1.6-fold in transitional milk, and 2.5-fold in mature milk. Thus, the increments in the total and free-form biotin amounts were directly related to the stages of lactation period, while the biotinidase activities had a minimal increase throughout the experimental period.

As shown in Fig. 1 (A), the concentrations of total biotin in 49 bovine milk samples increased throughout 98 days postpartum, and the values correlated significantly with the days of lactation $(r=0.718, p<0.01)$. A similar tendency was observed in the concentration of free-form biotin [Fig. 1 (B), $r=0.744$, $\mathrm{p}<0.01]$.

The relationship between the days of lactation and the ratio of free-form biotin to total biotin is shown in Fig. 2 ; there was no cor- 
Biotin and Biotinidase in Bovine Milk

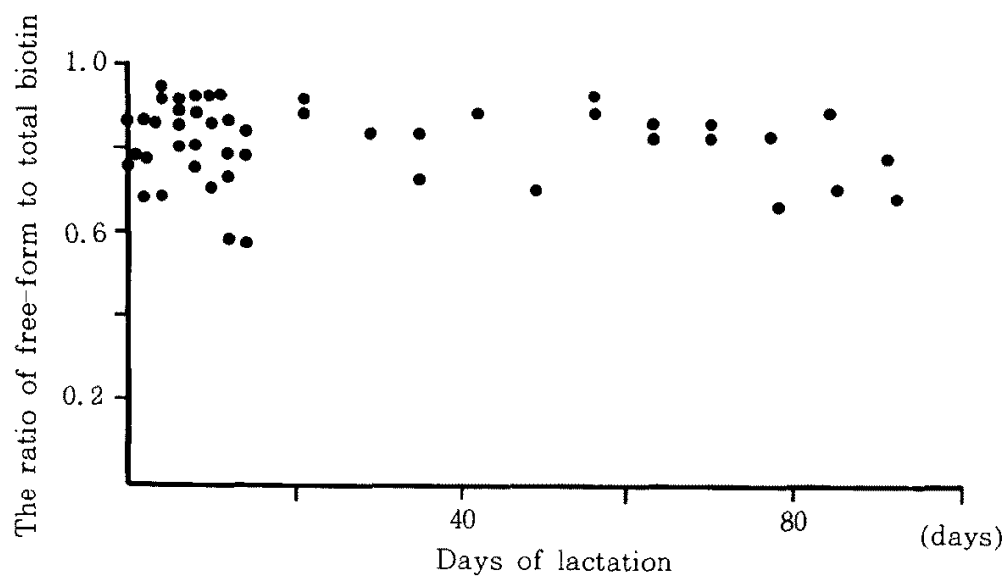

Fig. 2. The relationship between days of lactation and the ratio of free-form to total biotin.

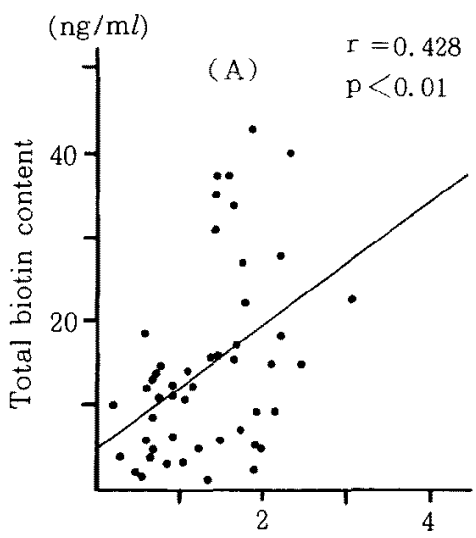

Biotinidase activity ( $\mathrm{pmol} / \mathrm{min} / \mathrm{mg})$

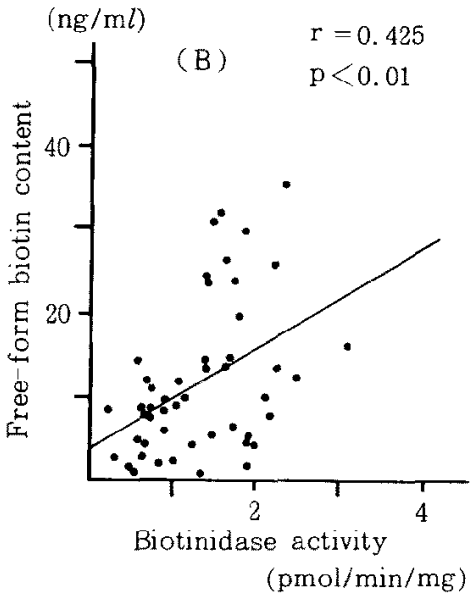

$(\mathrm{pmol} / \mathrm{min} / \mathrm{mg})$

Fig. 3. The relationship between biotinidase activity and total (A) and free-form (B) biotin contents in bovine milk.

relation between them.

Fig. 3 (A) and (B) show that the biotinidase activities significantly correlated with the total biotin contents $(r=0.428, p<0.01)$ and also with the free-form biotin contents $(r=$ $0.425, \mathrm{p}<0.01$ ).

\section{Discussion}

Previous studies by CAUSereT ${ }^{4)}$ and GreGORY et al. ${ }^{9 \prime}$ have shown that total biotin level in bovine milk was 21 to $43 \mathrm{ng} / \mathrm{ml}$, which was slightly higher than our data. The total biotin concentration of bovine milk increased with the progress of the lactation period in this experiment. Our results are consistent with those found in humans ${ }^{6,8,181}$, but are at variance with other studies ${ }^{9,16)}$ which showed a rise in bovine milk total biotin level within a few days postpartum.

These differences may be due to the differences in the stage of lactation studied and the methodology used.

Although it has been thought that biotin was present in milk in the free-form alone ${ }^{11}$, we 
found the bound-form as well as free-form biotins in bovine milk. We also demonstrated the increases in both total and free-form biotin levels as the days went on after delivery and the ratio of free-form to total biotin being about 0.81 throughout the lactation period.

Moreover, this is the first report on the presence of the biotinidase activity in bovine milk. The enzyme activity increased day by day postpartum, and correlated well with the concentrations of free-form biotin and total biotin. The origin or significance of the enzyme remains to be elucidated. However, the present results lead us to speculate that biotinidase plays a primary role in filling the biotin required by calves, and that an induction of biotinidase in maternal mammary gland is related to the regulation of the biotin concentrations in bovine milk.

Biotin deficiency has been observed in various mammalian species such as mouse, rat, pig, monkey, etc ${ }^{231}$. Skin and hair abnormalities and locomotor and reproductive problems are of ten found in biotin deficiency ${ }^{24)}$. In pig, it is well known that the animal requires a supply of biotin, because its administation improves the foot lesions and the increased piglets ${ }^{15}$. However, the necessity of biotin supplement in cattle has been poorly understood, although WIESE et al. ${ }^{251}$ reported that the biotin deficiency in the dairy calves characterized by paralysis of the hind quarters recovered completely by the subcutaneous or intravenous biotin injection.

The biotin deficiency in humans has been confounded with the zinc deficiency. Many cases of the "silent biotin deficiency" in bovine might be overlooked because of our poor knowlegde about the biotin deficiency.

Further studies concerning biotin in dairy science are required.

\section{Acknowledgements}

The authors wish to thank the staffs of Fuji Zootechnical Station, Tokyo University of $\mathrm{Ag}$ - riculture for their supplying of milk samples.

\section{Reference}

1) Baker, H., I.S. Thind, O. Frank, B. De Angelis, H. Caterini and D.B. Louria, Vitamin levels in low-birth-weight newborn infants and their mothers. Am. J. Obstet. Gynecol., 129: 521-524. 1977.

2) Baker, H., O. Frank, B. De Angelis, S. FEINGOLD and H.A. KaminetzKY, Role of placenta in maternal-fetal vitamin transfer in humans. Am. J. Obstet. Gynecol., 141 : 792-796. 1981.

3) Bowman, B.B., J.Selhub and 1.H. RosenBERG, Intestinal absorption of biotin in the rat. J. Nutr., 116 : 1266-1271. 1986.

4) CAUSERET, J., Vitamin value of an animal milk compared to that of human milk. Ann. Nutr. Aliment., 25: A313-A334. 1971.

5) Cremin, F.M. and P. Power, Vitamins in bovine and human milks. in Developments in Dairy Chemistry-3. (Fox, P.F. ed.) 388. Elsevier Applied Scientific Publishers. London. 1985.

6) Ford, J.E., A. Zechalko, J. Murphy and O.G. Brooke, Comparison of the $B$ vitamin composition of milk from mothers of preterm and term babies. Arch. Dis. Child. 58: 367-372. 1983.

7) Fukui, T., J. Orzumi and K. Innuma, The simple quantitative method of serum biotin using Lactobacillus. Byoutaiseirishi, 57: 28-32. 1989 (in Japanese).

8) Goldsmith, S.J., R.R. Eitenmiller, R.M. FEeley, H.M. Barnhart and F.C. Maddox, Biotin content of human milk during early lactational stages. Nutr. Res., 2 : 579-583. 1982

9) Gregory, M.E., J.E. Ford and S.K. Kon, The B-vitamin content of milk in relation to breed of cow and stage of lactation. J. Dairy Res., 25 : 447-456. 1958.

10) Gyorgy, P. and C.S. Rose, The liberation of biotin from the avidin-biotin complex (AB). Proc. Soc. Exp. Biol. Med., 53: 5557. 1943.

11) Hartman, A.M. and L.P. Dryden, The vitamins in milk and milk products. in Fundamentals of dairy chemistry. (WEBB, B.H. and A.H. Johnson, eds.) 300 . The Avi Publishing Company. Westport. 1965. 


\section{Biotin and Biotinidase in Bovine Milk}

12) Hayakawa, K. and J. Orzumi, Determination of biotinidase activity by liquid chromatography with fluorometric detection. J. Chromatogr., 383 : 148-152. 1986.

13) Knappe, J., W. Brummer and K. BiederBICK, Reinigung und eigenschaften der biotinidase aus schweinenieren und Lactobacillus Casei. Biochem. Z., 338: 599-613. 1963.

14) Kotvusalo, M. and J. Pispa, Biotinidase activity in animal tissues. Acta Physiol. Scand., 58: 13-19. 1963.

15) Kornegay, E.T., Biotin in Swine Nutrition. Ann. N. Y. Acad. Sci., 447: 112-121. 1985.

16) Lawrence, J.M., B.L. Herrington, L.A. MAYNARD, The nicotinic acid, biotin, pantothenic acid content of cow's milk. J. Nutr., 32 : 73-91. 1946.

17) Lowry, O.H., N.J. Rosebrough, A.L. FARr and R.J. Randall, Protein measurement with the folin phenol reagent. J. Biol. Chem, 193: 265-275. 1951.

18) MACY, I.G. and H.J. Kelly, Human milk and cow's milk in infant nutrition. in The mammary gland and its secretion. Vol. 2. (KoN, S.K. and A.T. CowIE, eds.) 265-304.
Academic press. New York. 1961.

19) SAID, H.M. and R. RedHA, A carriermediated system for transport of biotin in rat intestine in vitro. Am. J. Physiol. 252 : G 52-G 55. 1987.

20) SAID, H.M. and R. REDHA, Biotin transport in rat intestinal brush-border membrane vesicles. Biochim. Biophys. Acta 945 : 195-201. 1988.

21) Thoma, R.W. and W.H. Peterson, The enzymatic degradation of soluble bound biotin. J. Biol. Chem., $210: 569-579.1954$.

22) Thompson, R.C., R.E. Eakin and R.J. Wilimams, The extraction of biotin from tissues. Science, $94:$ 589-590. 1941.

23) Watanabe, T., Reproductive and embryotoxic effects of biotin deficiency in mam. mals. Vitamins (Japan), 64: 429-440. 1990 (in Japanese).

24) WhiterieAd, C.C., Assessment of biotin deficiency in animals. Ann. N. Y. Acad Sci., 447: 86-96. 1985.

25) Wrese, A.C., B.C. Johnson and W.B. Nevens, Biotin deficiency in the dairy calf. Proc. Soc. Exp. Biol. Med., 63: 521-522. 1946. 
Hirano, Honma, Daimatsu, Hayakawa, Otzumi, Zaima and Kanke

\title{
牛乳のビオチン含有量とビオチニダーゼ活性
}

\author{
平野雅彦・本間和宏・大松孝樹・早川 江* \\ 大泉 純 $*$ ・財満耕二・菅家祐輔
}

東京農業大学農学部，東京都世田谷区 156

*国立小坚病院小児医療研究センタ一, 東京都世田谷区 154

\begin{abstract}
牛乳中のビオチンの存在形態と, その経時的变化を明らかにするために, ホルスタイン 5 頭から 3 力 月間牛乳を採取し，Lactobacillus plantarum ATCC8014 を用いた新しいディスクプレート法によ り、その総ビオチン量と遊離型ビオチン量を测定した。

牛乳の総ビオチン含有量は, 出産後の日数の経過ととbに有意に増加し $(\mathrm{p}<0.01, \mathrm{r}=0.718)$, 遊 離型ビオチン量屯同様に有意に增加した（ $\mathrm{p}<0.01 ， \mathrm{r}=0.744 ）$ ．総ビオチン量に占める遊離型ビオチ ン量の割合は，日数の経過にかかわらず，泌乳期間を通して約 $81 \%$ と一定であった。

また牛乳のビオチニダーゼ活性は，初乳に比べ移行乳 $(\mathrm{p}<0.05)$ ，成乳 $(\mathrm{p}<0.01)$ と有意に上昇し， 更に総ビオチン量（ $\mathrm{p}<0.01 ， \mathrm{r}=0.428 ）$ ，遊離型ビオチン量（ $\mathrm{p}<0.01, \mathrm{r}=0.425 ）$ とも有意な相関を ホした。

以上の結果から，牛乳中のビオチニダーゼ活性は，牛乳の遊離型ビオチンや総ビオチン含有量に影響 していることが示唆された。
\end{abstract}

日畜会報, $62(11) ： 1048-1054,1991$ 